\title{
The Wolf Pack and the Upas Tree
}

On August 22, 1934, striking truck drivers celebrated a historic victory in their fight to make Minneapolis a union town. Carrying out three militant walkouts that year, led by a dedicated core of local Trotskyists, Local 574 of the International Brotherhood of Teamsters (IBT) won recognition at the majority of the city's trucking companies. Along with the San Francisco general strike and the Toledo Auto-Lite strike, the Minneapolis Teamsters' battle paved the way for the creation of the Congress of Industrial Organizations (CIO) and industry-wide unions in auto and steel. ${ }^{1}$ On Sunday, September 16, less than a month after workers voted in the Teamsters, William Bell Riley delivered a sermon to his Minneapolis First Baptist flock that portrayed the dark side of the strike. It was, for Riley, a menacing development that showed the evil confluence of communism, evolutionism, and the Jewish conspiracy.

Riley's animalistic theme was "The Russian Boll-WeevilBolshevism." He tied the strike to communism by quoting IBT president Daniel Tobin, who opposed the local Trotskyist leaders. ${ }^{2}$ "The purpose 
of the Communists," Tobin had said, "is to overthrow American institutions." Not only had "hundreds of Communists" invaded Minneapolis to "irritate and agitate" during the Teamsters strikes, Riley explained, but they were criminals and noncitizens. Using another animalistic analogy, Riley added that these "agitators" were drawn to strikes in the same way that "green bottle flies" were attracted to a rotting corpse, where they lay their eggs and produce more of their own kind.

The spreading communist invasion, Riley told his flock, was part of a diabolical plan, outlined in the Protocols of the Elders of Zion. The agents carrying out the "Protocol plan" were the criminal and Jewish Bolshevik leaders. These "inhuman beasts," said Riley, were using "terrorism" to maintain control over the Russian people. In the United States, as specified in Protocol No. 2, they were spreading the ideas of Darwin, Marx, and Nietzsche. In the name of science, the Protocol plotters were deliberately confusing and demoralizing the American people, who would eventually call for a ruler to bring order from the communist-caused chaos. Finally, the Elders of Zion, prophesied by John in Revelation 13, would crown their "sovereign lord"- the Antichrist—as "king of the whole world."3

In the year following the Teamsters strikes, Riley would flesh out the horrors of the Protocol plan in sermons drawing on the work of his protégé Dan Gilbert, who would soon join Riley in his exposure of the CIO's industrial unionism as a satanic plot. But in his early works Gilbert explained how communist influence and evolutionary teachings at the nation's colleges were sending young people down a hellhole of sexual immorality, meaninglessness, and crime. ${ }^{4}$ Riley also liked Gilbert's Evolution: The Root of All Isms (1935), which taught that evolution was the source of Nietzschean amorality, Marxian communism, determinism, atheism, and various "Free-Love-Isms." ${ }^{5}$ Giving a new twist to the horticultural analogy, Gilbert dubbed evolution the "upas tree of atheistcommunism," referring to the legendarily poisonous Antiaris toxicaria of Indonesia. ${ }^{6}$ Whereas Nietzsche promoted an amorality based on the individual "superman," explained Gilbert, Marx pushed a collective proletarian morality based on lust, hate, class-consciousness, and brutality, or, as Gilbert put it, the ethics of the "wolf pack."7

The integrated web of evils represented by communism, evolution, free love, the hidden hand of the international Jewish conspiracy, and labor revolt-this was the target for Riley, Gilbert, and their fundamentalist 


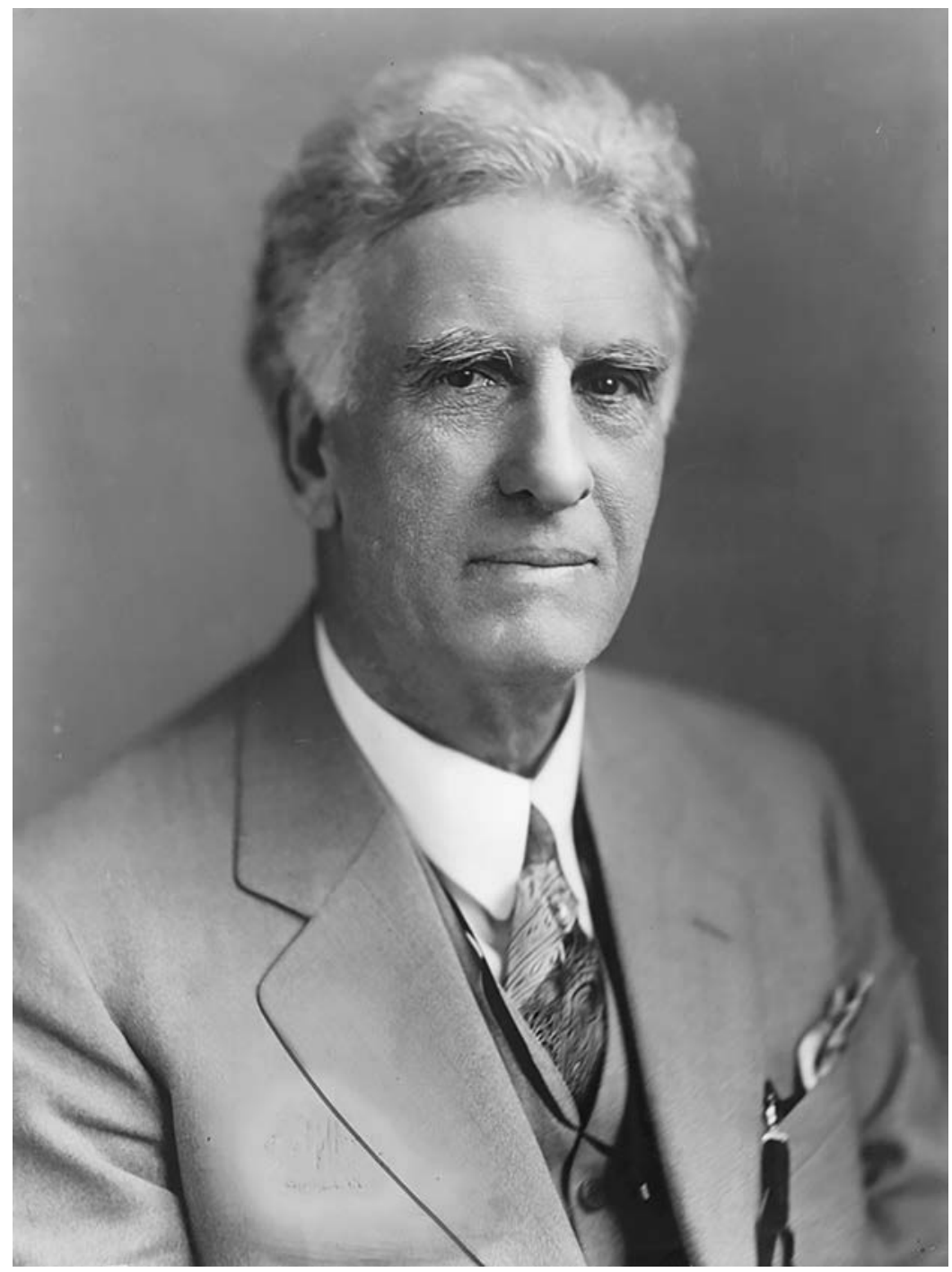

Figure 8. Rev. William Bell Riley, c. 1930. Known as the "Grand Old Man of Fundamentalism," Riley (1861-1947) led the fight to ban evolution in the 1920s, and by the 1930s attributed evolution to a Jewish-Communist conspiracy. Courtesy of Berntsen Library, University of Northwestern-St. Paul. 
counterparts from the early 1930s through the end of World War II and beyond. They were joined by veterans of the fight, including J. Frank Norris and Gerald Winrod. For Riley and Winrod, anticommunism led to public support for Adolf Hitler and the Nazi Party. The decade also witnessed the arrival and amplification of new voices making connections between evolution, communism, and moral decline: Elizabeth Knauss, premillennialist and anticommunist, and Aimee Semple McPherson, the monumentally popular founder of the Los Angeles-based Church of the Foursquare Gospel.

The appointment of Adolf Hitler as Reichskanzler of Germany on January 30, 1933, and the inauguration of Franklin D. Roosevelt as president of the US on March 4 of the following year were two critical signs of the times that set off the 1930s from the previous decade. They signaled a new context in which the battle against evolution would be fought: economic depression, labor revolt, political polarization, and world war. William Bell Riley's earliest commentary on the Nazi regime came five months after Hitler took power. Riley knew about protests in the US against the Nazi regime but had little sympathy with them. The German state had a right to defend itself, and the main threat it faced was communism. As Riley wrote, "The question involved here is not a question of Jewry at all; it is a question of Communism, and nothing more." Riley hated hypocritical liberal preachers who called on the US government to recognize Soviet Russia and yet spoke at meetings denouncing Hitler. Millions perished in Stalin's Russia, and they said nothing. But "the moment a Jew-Communist in Germany had his store closed, they were tearing their hair," wrote Riley. To deepen the point that Jews embodied the communist threat, Riley claimed that when he debated evolution before student groups, "the most vicious atheists and the most intolerable Communists that I have met, have been Jews from Russia, and other countries."

In light of subsequent events, the last paragraph of Riley's unapologetic anti-Jewish and pro-Nazi article is worth quoting at length:

Jewry, from the day that she crucified Jesus Christ until the present time, has given many occasions for her own rejection and for that opposition which she has politically pronounced persecution. Hear Hitler, who speaks from 
first-hand knowledge: "The Jew is the cause and beneficiary of our slavery. The Jew has caused our misery, and today he lives on our troubles. That is the reason that as Nationalists, we are enemies of the Jew. He has ruined our race, rotted our morals, corrupted our traditions, and broken our power." 8

The "rotting" of morals spoke powerfully to Riley's readers, who were familiar with the charge. It reinforced Riley's point that Jewish Communists had assailed him when he critiqued evolutionary science. The attribution to "Jews" of everything that had gone wrong provided a handy way to explain the real troubles facing the masses of German people. As suggested by Riley's invocation of the "Jew-Communist" store owner, the Jew as enemy was a remarkably shape-shifting character.

Riley gave more positive publicity to the "Vienna painter" in a January 1934 Pilot article. He began by flaying liberals for hypocrisy in the face of starvation, murder, and religious persecution in Soviet Russia, which he called the "beast of materialism." Playing on the historicist premillennial idea that the beast had made an earlier appearance in the French Revolution, Riley described the decline of morality in revolutionary France in familiar animalistic terms: "Citizens had to awaken in a moral pigsty, and recognize the swinish level to which they had come." Turning now to Germany, Riley explained that Hitler's “anti-semitism has some just basis." He cited an article that praised Hitler for reducing unemployment, restoring law and order, and promoting a unified nationalistic spirit. Riley even suggested that Hitler was a divine agent. "To me, at least," Riley wrote, "it was nothing short of help from on high that enabled him to snatch Germany from the very jaws of atheistic Communism." If he had to choose between Germany and Russia, Riley concluded, he would choose Hitler's Germany "a thousand-fold." 9

By early 1934, no one attending Riley's sermons or reading the Pilot could doubt his support for Hitler. But he went further in The Protocols and Communism (1934), which tied the evildoings of Jew-Communists to a worldwide conspiracy. ${ }^{10}$ Riley knew that the Protocols might be a forgery. A number of prominent fundamentalists-including William Jennings Bryan-had condemned it as such. ${ }^{11}$ But his "concession" on this point- "Jews in general deny that their elders wrote it"-implied that such "elders" existed, thus underlining the document's authenticity. ${ }^{12}$ Riley repeatedly quoted from the Protocols to prove Jews' evil intentions. 
World War I, for example, was a Jewish plot to create "pandemonium and destruction." Jews also created the motion picture industry, which Riley identified as "the most vicious of all immoral, educational, and communistic influences." The Jewish-dominated Communist International ordered the Minneapolis and Toledo strikes, "with their brutal murders." And in regard to Jewish control of education, Riley repeated his point that Jews were particularly prone to "advocate the evolutionary hypothesis." 13 By teaching young people that they were animals, Jews contributed to the "rotting morals" evoked by Hitler.

It is only with this plot in mind that one can understand Riley's continuing indifference to the fate of Jews in Germany even in late 1938 after Kristallnacht. On November 9 and 10, Nazi gangs killed ninety-one Jews, beat hundreds, ransacked thousands of Jewish-owned shops and homes, destroyed more than one thousand synagogues, and arrested thirty thousand. ${ }^{14}$ The details of the attacks were widely reported in the United States. A typical headline from the Dallas Morning News read, "Hysterical Nazis Wreck Thousands of Jewish Shops, Burn Synagogues in Wild Orgy of Looting and Terror; Policemen Refuse to Halt Organized Riots in Germany."

But on November 20, ten days after this news reached Americans, Riley gave yet another sermon minimizing the Nazi threat and blaming Jews. The main enemy, he reminded his flock, were the Communists ruling Russia. Their leaders included "Jews from New York City." The Nazis, to their credit, had stopped them. And the Communists were far more sinister than the Nazis—a "hundredfold" more. In another formulation, Riley compared the threat of "one" dictator in Germany with 541 in Russia. ${ }^{15}$ In the course of four years, the differential threat level had confusingly gone down by a power of ten-from a thousand to one hundred-and then back up to over five hundred. But Riley's followers got the point. They were to shed no tears for the Jews of Germany.

There were other leading fundamentalists in America-J. Frank Norris among them-who did not share Riley's Jew hatred or who did not express it publicly. ${ }^{16}$ But from his base in Wichita, Kansas, Gerald Winrod was marching in step with Riley on the subject of the Protocols, Jews, evolution, and the Nazi regime. Around the time that Riley began writing about the Elders of Zion, Winrod discovered the Protocols. In 1933, 
Winrod claimed that a group of some three hundred men had gained control "of the gold of the nations," were working secretly "in the shadows," and aimed to create "chaos" so that they could overthrow the existing order. Winrod reported that the group of men "are wealthy Jews." Much as Riley had done, Winrod reprinted pro-Nazi news from Germany without comment. In April 1933, he drew from a press report indicating the Jewish shops were closed in Essen, Germany, with Nazi flags hoisted above their doors. Dr. Wilhelm Frick, Hitler's minister of the interior, explained that the Nazis would clear Jews out of universities, the production of film and literature, and the press. The "Semitic sensualists," Frick said, would be stopped from spreading their "nefarious international poison." And so Winrod's Defender story ended. ${ }^{17}$

A month later, Winrod reiterated his claims about the Protocols and his support for the Führer. Once again, Hitler's actions-his “alleged Jewish persecutions" - toward German Jews were justified. After all, the Protocols tell us, the "Semitic men of finance" were seeking to create "chaos" and also to "overthrow the morals of the Gentiles." In contrast to the incessant negative characterization of the Soviet leaders as animals, Winrod uses the same language to praise the Nazi leader. Hitler, Winrod wrote, was "like a wild beast that refuses to be controlled." 18 Along the same lines, Winrod justified violent, Nazi-like tactics in the United States. Several months after the Minneapolis Teamsters strikes, Winrod reported that vandals had attacked a Minneapolis bookstore that sold "sinister Red literature." They broke the plate glass, stole books, burned them, and ransacked the property. On a highway on the outskirts of the city, where only ashes remained from the burned books, signs read "FIRST WARNING TO COMMUNISTS" and "BURNED COMMUNIST LITERATURE." Winrod issued no disapproval of this "bestial" behavior in the service of a righteous cause. ${ }^{19}$

At the same time that Winrod was praising Hitler, he was also sizing up President Franklin Roosevelt. Like many other premillennialists, Winrod came to see Roosevelt as the Antichrist. ${ }^{20}$ Winrod joined them in suspecting that the blue eagle of the National Recovery Administration was the "mark of the beast" of the book of Revelation. Unlike most of his counterparts, however, Winrod focused on the specifically Jewish elements of the threat. For Winrod, the essential background was the nefarious activity of the Illuminati, a secret, freethinking organization founded in 1776 
by Adam Weishaupt, who was trained as a Jesuit priest but was born Jewish. As Winrod explained in Adam Weishaupt: Human Devil (1936), the Illuminati's Jewish origins explained its ability to cause revolutions, wars, and economic depressions, including the 1929 stock market crash. Both the French and Russian revolutions, according to Winrod, were organized by Jewish plotters as an "onslaught against Christianity and the moral and social systems." The "Jew-ocracy of Moscow" was implicated in both evolutionary immoralism and the "socialistic" New Deal. ${ }^{21}$

Winrod's historical investigation led him to an irresistible conclusion: Franklin Delano Roosevelt was secretly Jewish. William Dudley Pelley's pro-Nazi Silver Shirts had already been circulating the allegation of Roosevelt's Jewish ancestry for a number of years. ${ }^{22}$ But Winrod did his part to make it stick. A few weeks before the 1936 elections, he announced the news in his tabloid, the Revealer. Featuring a graphic of the Roosevelt family tree, the front-page story led readers to believe that the president was descended from Dutch Jews named Rosenvelt. Roosevelt's Jewish "racial" origins explained his "natural bent toward radicalism" and made it clear why he had appointed left-wingers, many of them Jews, to positions in the New Deal administration. As Winrod summed it up, the New Deal was not just a political challenge for fundamentalists but a "biological" one. ${ }^{23}$ In a broader sense, that "biological" challenge, from Winrod's standpoint, encompassed not only Jewish racial characteristics but also their communistic ability to spread the immoralism of evolutionary science. In fingering Roosevelt as a closet Jew, Winrod outdid Hitler. The Nazi regime made much of Roosevelt as "a tool of the Jewish world conspiracy," tying him to Freemasons, bankers, and other evil forces. But they apparently saw no need to identify him as Jewish. ${ }^{24}$

Where Winrod and Riley felt no compunction about openly praising Hitler and damning Jews, their allies were more circumspect. Most notable was Dan W. Gilbert (1911-1962), the West Coast journalist who made a major contribution to the communist-evolution-free love nexus during the Depression decade. ${ }^{25}$ Though scarcely remembered today, he spoke with an unusually clear and persuasive voice to a large audience of conservative Christians. Born in 1911 in Oakdale, California, where his father, Amos Lawrence Gilbert, ran a successful farm equipment company, 
Dan Gilbert attended the University of Nevada and then launched his career as a newspaper reporter and columnist. ${ }^{26}$ In the mid-1930s, the young Gilbert joined forces with Riley, teaching at Northwestern, preaching at First Baptist, and writing for the Pilot. He became a contributing editor in 1939 , served as the general secretary for the relatively quiescent World's Christian Fundamentals Association, and during World War II relocated to Washington, where he edited the National Republic and ran the Christian News Bureau. After the war, he was a prominent voice in the $\mathrm{Na}-$ tional Association of Evangelicals and worked as a radio evangelist until his death in $1962 .{ }^{27}$

While Gilbert wrote during the 1930s and '40s on a wide range of topics, his main contribution to fundamentalist literature focused on the connection between communism, evolution, and new views of sexuality. His main targets were V.F. Calverton (1900-1940) and Samuel Schmalhausen (1890-1964), two communist-minded intellectuals who wrote widely on sex. Born George Goetz into a working-class family in Baltimore, Calverton founded the Modern Quarterly in 1923, a highly influential left-wing non-party journal of literary, artistic, and political commentary. ${ }^{28} \mathrm{~A}$ Jewish socialist ten years Calverton's senior, Samuel Daniel Schmalhausen had begun his career teaching English at DeWitt Clinton High School in New York City. The school's progressive-minded biology teachers included George Hunter, whose Civic Biology stood at the center of the 1925 Scopes trial. ${ }^{29}$ Thanks to socialist writer Upton Sinclair, Schmalhausen gained national attention when he was fired by the city's school board for encouraging sedition in his students. ${ }^{30}$ Following his dismissal, he pursued a strong interest in Freudian psychoanalysis, set up his own psychology institute, and began to write on the subject of sex and society. His irreverent and often comical writing style led commentators to describe him as the "Groucho Marx of the Left." 31

Dan Gilbert's first foray into this political minefield came with Crucifying Christ in Our Colleges (1933). Drawing on his experience at the University of Nevada as well as stories told to him by a variety of pseudonymous student informants, Gilbert constructed the book as a series of cautionary tales about the moral and political dangers of the modern, secular, pro-evolutionary university. Each chapter focused on a different student who had been led astray by the "ubiquitous anti-Christ, anti-God, antiBible, anti-moral professor." The epigraph from Dr. Frederick P. Woellner, 
an associate professor of education at UCLA, identified the source of various evil "fads" and "isms" as the excessive presence of "Communist teachers" in secondary and postsecondary schools. "We should kick them out without argument or delay," said Woellner. Gilbert evidently agreed.

The victims of these modern Pied Pipers of moral ruin were various. "Agnes" studied evolutionary biology and the cosmic evolutionism of Herbert Spencer. She lost her moral compass, life lost all meaning, and she killed herself. "Evelyn" had been a good Christian girl, but at college she learned about evolution and began living a hedonistic life. She had once sung in her church choir, but now her "sweet soprano" was repurposed to the delight of "jazz maniacs." She dropped out of college and was never heard from again. "Lester" read Joseph LeConte on evolutionary geology and soon joined the socialists. He figured that that since there was no eternal reward, he would fight for justice in the here and now. But when he realized that the solar system was a product of evolution and that the sun would eventually run cold, his outlook became grim, and he sank deep into alcoholism. "Jean" was put off by the sexual immorality she encountered as a freshman. But once she read Engels, Bebel, and the sociologist Lester Ward, she renounced Christianity, "gloried in night dancing," went camping with her boyfriend, became pregnant, had a botched abortion, and now lingered on the brink of death. ${ }^{32}$

Gilbert's message was unmistakable: the teachings of evolution and Marxism were inevitably and dangerously intertwined. They were sweeping the nation's campuses. They undermined any basis for a meaningful moral code. And they led to disastrous consequences for the nation's young people. To illustrate the content of such teachings, Gilbert quoted from Marxist authorities, biological evolutionists, and social scientists with an evolutionary perspective. He also quoted unnamed professors whose classes he had suffered through at Nevada. One Marxist economist recited the words to the "Internationale" in class. A sociologist told students that America would eventually recognize that abortions were "morally and socially right" and would repeal laws against them just as the "enlightened regime" in Russia had done. ${ }^{33}$ To support his claim that evolution-inspired, atheistic communism led to crime, Gilbert quoted George Barry O’Toole, who compared workers to "starving swine" who push aside their bloated "coupon-holding capitalist" brethren at the troughs they had once monopolized. 
Crucifying Christ put Dan Gilbert on the map. The book was favorably reviewed by evangelical publications. Gilbert was invited to speak by a variety of Christian groups, who welcomed his explanation for the apparent moral decline of the nation. At a convention of Gideons, one attendee reported, Gilbert told his tales of woe in "frightening detail." After his talk ended with a hymn and prayer, he did a "brisk sale" of the book, which sold for one dollar. ${ }^{34}$ Christian educators took note. One prominent reviewer thought Gilbert had shown "conclusively” how students' Christian faith was "often destroyed" by their college experience. ${ }^{35}$

In 1935, Gilbert followed up Crucifying with Evolution: The Root of All Isms. What his second book lacked in extended, detailed personal portraits of evolution's victims it made up for with a heavy emphasis on sex. The "upas-tree" of "atheist-communism," according to Gilbert, had grown from five interrelated, evolutionary roots: Nietzscheanism, Marxism, Determinism, and Free-Love-Isms. It was the latter that formed the figurative and literal centerpiece of the book. In the one-page table of contents, the chapter on "The Root of Free-Love-Isms" took up about 40 percent of the vertical space, due to the detail provided on its subsections. They included "Schmalhausen's Philosophy of Sex Promiscuity," "Freud's Advocacy of Free Sex Indulgence," "Free-Love Sociology," "[Bertrand] Russell's Doctrine of Sex Freedom for the Young," "Sexual Animalism (as indoctrinated by some Professors of Anthropology)," and “Briffault's Immoralism.” Just as Gilbert introduced Crucifying with an epigraph about the danger of communist-minded professors, his second book began by quoting Giuseppe Tuccimei (no doubt, thanks again to O'Toole) on how the evolutionary philosophy had produced the consequences of "socialism and anarchy." 36

Before elaborating on evolution's sexual sins, Gilbert placed the "beast" doctrine in the context of both Nietzsche's and Marx's support for Darwin's evolutionary concept along with the notion that "might makes right." To support his claim that Marxists embrace any means to the communist end, Gilbert quoted Lenin as follows: "The dictatorship of the proletariat is nothing else than power based upon force and limited by nothing-by no kind of law and by absolutely no rule." He also has Lenin saying that "all children should be present at the executions and should rejoice in the death of the enemies of the proletariat-Marx took savage delight in contemplating the bloody extinction of the proletariat's class 
enemies." Summarizing the Marxists on this question, Gilbert concludes that anything that helps to "hasten socialism" is right, no matter how reprehensible. ${ }^{37}$

Gilbert's desire to paint Marxists in the darkest colors led to loose standards of accuracy. In the first case, Gilbert misquoted Lenin and took him out of context. Lenin was quoting himself, addressing the Constitutional Democrats (Cadets) after the failed 1905 revolution. He actually said that any form of "dictatorship means unlimited power, based on force, not on law." The distorted version of the quote was circulating in the national press while Gilbert was writing his book. ${ }^{38}$ In the second case, it is impossible to find any credible source for the quotation about the bloodthirsty Marx. ${ }^{39}$ Other comments by Gilbert about Marx are simply inaccurate, such as "Marx's theory was that human nature is all bad." One original contribution, however, was Gilbert's ability to weave into his antievolutionary scheme Marx's concept of profit as surplus value extracted from the worker. Such an idea, wrote Gilbert, "appears to rest largely on the presumption that man is a soulless beast ... who knows not the meaning of charity, kindness, and justice." ${ }^{40}$

In Gilbert's eyes, Marx's "wolf pack" ethics were detestable. But it was the "barnyard ethics" of "sex anarchy" that truly condemned the theory of man's beast ancestry. Gilbert began his examination with the writings of Schmalhausen, whom the author identified, with some exaggeration, as the most "popular and persistent champion" of the "New Morality." This Groucho Marx of the Left celebrated all that Gilbert found repulsive and immoral: sexual promiscuity, homosexuality, masturbation, and various unnamed forms of "perversion." As Gilbert correctly noted, Schmalhausen's ideas about sex were based on the evolutionary idea of humanity's "ancient animal history" and on the observation of our primate "monkey" cousins in their natural habitats. The resulting quotations from Schmalhausen were meant to shock Gilbert's readers: Nature "objects neither to incest nor homosexuality nor playful perversions"; "Promiscuity is in the nature of things"; "animals enjoy the practices of masturbation and homosexuality"; "we are born perverts." In contrast to traditional moralists who pointed to the behavior of animals in the wild as an example of how human beings should not behave, writes Gilbert, Schmalhausen turned things upside down and used the same observations to argue that such behavior is "NATURAL and PROPER" for human beings. ${ }^{41}$ 
From here Gilbert turned to the man who, he claimed, had done more to promote sexual immorality in the nation's youth than any other: Sigmund Freud. Quoting mainly from textbooks that drew on Freudian ideas, Gilbert claimed that Freud had caused an "incalculable" degree of "moral ruin." Freud's viewpoint was based on evolution, as expressed in the master's formulation in A General Introduction to Psychoanalysis (1917) that "man is a pleasure-seeking animal." Since sexual desire was akin to hunger that needed to be satisfied, the frustration of such desire led to pathological results. Giving free rein to sexual impulses was healthy. Support came from psychologist Daniel Bell Leary, who explained that human behavior was based on two drives, hunger for food and "the racepreservative sex hunger"; from psychologist W.B. Pillsbury, who wrote that sex was "one of the strong impulses of every normal individual" (Gilbert's emphasis added); and from Barbara Low, who described Freud's concept of the unconscious mind as consisting of "primitive inherited impulses and desires," which "remain indestructible." As Gilbert summed up Freudian thinking for his readers, "Fundamentally and NORMALLY man is a sex-mad, pleasure-seeking animal." 42

It was not only psychologists who were making this dangerous argument but sociologists and anthropologists as well. Columbia's F.H. Giddings, Gilbert reminded readers, had publicly defended Russian novelist Maxim Gorky when he arrived in the US without his wife and in company with his lover. ${ }^{43}$ It made sense to Gilbert that an evolutionary sociologist like Giddings would write, "The new sexual relations of the future will be promiscuity on a higher plane." Joining Giddings in Gilbert's pantheon was Friedrich Engels, whom Gilbert dubbed as "one of the greatest" proponents of evolutionary immorality. In Origin of the Family, Gilbert charged, Engels affirmed the "brute ancestry" of humanity seven times and frankly admitted that it was the basis of his "case for free-love." Though sociologist Lester Ward was no Marxist, Gilbert also lumped him with Engels as someone who "substantially endorses the Marxist doctrine that 'marriage is legalized prostitution." "44 And he took aim at anthropologist Robert Briffault, whose review of studies of apes in the wild led him to argue that chastity was unnatural. Gilbert was particularly alarmed by Briffault's application of his conclusions to women, based on the following observation of apes: "The sexual activity of females is as pronounced and as promiscuous as that of the males." 45 
While not every author cited by Gilbert was a Marxist, it would have been difficult for a casual reader to miss the evil thread running between evolutionism, free love, and communist doctrine. It is surprising, then, that in his discussion of Schmalhausen, Gilbert failed to mention the man's Marxist sympathies. But he corrected this omission in a series of articles he wrote for Riley's Pilot in the late 1930s. Gilbert told readers that the "Soviet system" aimed to eradicate morality by teaching "animalism" as both an intellectual philosophy and as a "way of life"-that is, as evolutionary science and sexual promiscuity. Gilbert featured a 1930 Schmalhausen essay on the family, which explained modern neuroses as the logical result of the repression of sexuality embodied in "home, sweet home" and promised that such problems would disappear under "a communistic form of society." ${ }^{46}$ In a transformed environment, according to Schmalhausen, the sex urge would be expressed in "acts of social compassion and humanistic love." Based on this damning evidence, Gilbert warned readers that the professors who were crucifying Christ and undermining the family on the nation's campuses were "advancing the communistic cause." ${ }^{47}$ In this way, Gilbert's Pilot articles reinforced the red connection to evolution that he had written about in 1935. Unlike Crucifying Christ, Gilbert's Evolution: The Root of All Isms appeared in only one edition, but it was still offered for sale at Northwestern Bible conferences as late as 1942 , seven years after publication. ${ }^{48}$ Schooled by William Bell Riley on evolutionary evils, Gilbert, in his relentless and detailed focus on evolution, communism, and sexual immorality, worked to magnify and extend the reach of his mentor's ideas.

Given the anxiety Dan Gilbert sought to generate by the stories of "Evelyn," “Agnes," and "Jean"-young, educated, openly sexual, independent-minded women-one might expect to find but few women in the leading ranks of American fundamentalism in the 1930s. Indeed, their presence had declined, as the result of what historian Margaret Bendroth calls the "growing masculine dominance of fundamentalism."49 And yet a number of women evangelists and writers did make some of the same connections men made between evolution, communism, the Jewish conspiracy, and Satan. Among them was one of the few women who exercised leadership in the WCFA: premillennialist writer and lecturer Elizabeth Knauss (1885-?). ${ }^{50}$ Hailing from Davenport, Iowa, Knauss 
was active in the local WCFA branch in the early twenties, heading up its Young People's Gospel team, which traveled around the region to provide music for fundamentalist revival preaching. ${ }^{51}$ By 1928 , Knauss was the general secretary of the Iowa WCFA, and she spoke widely around the country about the dangers of Bolshevism. ${ }^{52}$

In the spring of 1931, Knauss visited the anthracite coalfields of Scranton, Pennsylvania, to give a series of talks at local churches. Communism was on the minds of local residents as the party had considerable success recruiting local coal miners into an Unemployed League, under the effective leadership of recently arrived party leader Steve Nelson. ${ }^{53}$ That same year, Knauss published her views in The Menace of Bolshevism in America and throughout the World, a twenty-four-page pamphlet that went through at least six editions. ${ }^{54}$ Over the next two years, a series of articles by Knauss, drawing heavily from the pamphlet, appeared in Riley's Pilot.

Knauss began her study of Bolshevism some six years earlier when she first encountered the Protocols. Quoting Henry Ford, Knauss proclaimed her judgment that the document was "authentic." A group of "apostate Jews," wrote Knauss, were now carrying out their "diabolical" plan. The fact that a large majority of Bolshevik leaders were of Jewish origin but concealed this fact with pen names was circumstantial proof. ${ }^{55}$ To any Christian who might question why the spread of Jewish-inspired Bolshevism was truly dangerous, Knauss sought to clarify that their main objectives were to destroy home, church, government, and schools. Her evidence included stories about the dire results of the Bolshevik Revolution for Russian women and children, various quotes from Bolshevik leaders purporting to show their monstrous ambitions, a description of moral decline in the United States, and an account of the effects of the spread of Bolshevism in China.

Relying on published newspaper and magazine reports from Russia, and quoting generously from them, Knauss shared a nightmare vision with her readers that would have been familiar to Defender subscribers. She retold the story brought to light by George McCready Price in Socialism in the Test-Tube about the new public schools organized by Soviet commissar of education Lunacharsky. Adding a detail Price had omitted, Knauss noted that boys and girls occupied the same dormitories at the state boarding school. Knauss also made it clear that the horror of Bolshevism was about both morality and power. These young Bolsheviks, 
complained an author quoted by Knauss, were "learning to shoot straight at the mark of full equality of the sexes," as part of their future leadership training. ${ }^{56}$ In this 1930 s culture war, gender relations and class struggle were intimately intertwined.

Implying that "full equality" was not a desirable goal, Knauss said nothing about the real measures that the young Soviet Union had taken to equalize conditions for the sexes. She did, however, give full rein to accounts of the "nationalization" of Soviet women. According to a letter written by a former Russian aristocrat, from which Knauss quoted, Red Army commanders in one town had carried out a "drive" to capture women for the troops. Soldiers raped them and then killed them and threw their bodies in the river. Official Soviet documents, claimed Knauss, corroborated these accounts and spoke of "permits" issued to commissars to communize the women. She also referred to "hair raising" stories that were too terrible to relate to a "mixed audience," and to another instance of a particularly "bestial type" of behavior. ${ }^{57}$

To reinforce the familiar animalistic idea that the Bolshevists were beasts without any sense of human values, Knauss also shared with readers quotations attributed to Lenin and Lunacharsky that emphasized the value of hating family and community members. From Lenin: "Children must be taught to hate their parents if they are not communists. If they are, then the child need not respect them, need no longer worry about them." And from Lunacharsky: "Christian love is an obstacle to the development of the Revolution. Down with the love of one's neighbour. What we need is hatred." 58 Once again, these quotations were almost certainly fabricated. ${ }^{59}$ But they circulated widely. In making his case in Congress for nonrecognition of Soviet Russia in the early 1930s, Senator Arthur Raymond Robinson (R-IN) repeatedly quoted Lenin and Lunacharsky's fondness for hatred. In a pamphlet published in 1930 and timed to coincide with Pope Pius X's prayer for Russian Christians, Father Edmund A. Walsh, the vice president of Georgetown University, included the same Soviet "utterances." ${ }^{60}$ Like the spurious Lenin quotation employed by Dan Gilbert, this "factual" evidence effectively portrayed communists as amoral devils.

Not only were Knauss's lurid description of Russian conditions akin to articles appearing in Winrod's publication, but she shared as well his alarm at events in China. Knauss relied on the reporting of Rev. Edgar E. Strother, a Moody Bible Institute-trained missionary based in Shanghai ${ }^{61}$ 
According to Strother, Moscow had fooled Americans into thinking that the Chinese revolution was an indigenous movement, whereas the Russian Communists were actually pulling the strings. As an example of the bestial behavior practiced by communists, Knauss shared Strother's story of a "group of Bolshevized Chinese farmers who recently stoned to death a Chinese pastor at Yochow," claiming that he was in league with the imperialists. This incident showed that the "mad dog" of Bolshevism had to be stopped. ${ }^{62}$

Strother was useful for Knauss's case in one other respect: he was a devoted believer in the Protocols. He arranged for the publication of the first China edition of the book, in English, printed in Shanghai. As quoted by Knauss, Strother showed how not only communism but modernist religion was also a creation of the Jews. Just as William Bell Riley had invoked the culpability of "Jewry," quoting Hitler, for the Crucifixion of Christ, so did Strother specify that the Jewish Protocol plotters were "JEWS OF WHOM JUDAS ISCARIOT AND THE HYPOCRITICAL SCRIBES AND PHARISEES WERE A PROTOTYPE.”

Describing Bolshevism as a form of rampaging "Satanism" loose in China and Russia, Knauss also called attention to its inroads into the life of Christians in the United States. In capital letters, she warned readers that "BOLSHEVISM IS HERE." Spread by "multitudes of agents," its effects could be seen in various signs of moral decline: the support of college students for "companionate marriage," the "near nudity" on America's beaches, the appearance of atheist youth movements, and the teaching of evolution, which ushers young people into years of "pernicious, soul-destroying instruction." Summing up the significance of the multifaceted Bolshevist menace, Knauss concluded that it reflected the "spirit of ANTI-CHRIST."63

The strategies that Elizabeth Knauss pursued in underlining the dangers of communism to Christians around the nation in the early 1930s were fundamentally similar to those employed by Riley and Winrod. All three accepted the claims of the Protocols; they identified Bolshevism with Satan and immoralism; and they connected evolution and communism. One notable difference in Knauss was the disproportionate amount of her text that consisted of quotations from male missionaries and ministers. As she was one of the few women leaders of the WCFA, her emphasis on women and children as victims of communism (and at least obliquely, 
evolution) may have stemmed in part from her need to establish a politically acceptable arena of operation. And yet, Knauss had expanded the audience for the anticommunist, antievolutionist message. She was determined to carry on her work to those "still in ignorance who need enlightenment." ${ }^{64}$

If Elizabeth Knauss stayed within a relatively traditional mold in delivering her message, Aimee Semple McPherson (1890-1944), her diehard anticommunist and antievolutionist counterpart on the West Coast, broke that mold. ${ }^{65}$ Born Aimee Kennedy on a farm in Ontario, she met Irishborn Pentecostal minister Robert Semple at the age of seventeen and was swept up in enthusiasm for a Pentecostal variant of fundamentalism. Eventually landing in Los Angeles, she raised the money to erect the giant fifty-three-hundred-seat Angelus Temple in 1923, headquarters for McPherson's International Church of the Foursquare Gospel. Drawing on Pentecostal and holiness traditions that identified four aspects of Jesussavior, healer, baptizer, and coming king-Sister Aimee, as she was known to millions, took an ecumenical approach, welcoming those from a wide variety of denominations into her church. ${ }^{66}$ Dressed in white, McPherson became a celebrity preacher known for her "illustrated sermons," elaborately staged pageants with actors in costume, props, and her own dramatic preaching at its center.

Aimee Semple McPherson was an atypical fundamentalist. Not only was her church nondenominational and ecumenical—unlike those of Riley and Norris-she boasted of her faith-healing ability and spoke in tongues, at a time when Baptist fundamentalists like Norris were going overboard to pin the charge of Pentecostalism on their rivals. McPherson was also more open to the value of Social Gospel-inspired political action (and supported Franklin Roosevelt until her death in 1944). Most strikingly, she was a proto-feminist who pushed the boundaries of female "respectability." The Bible college she established in the 1920s ordained women ministers. She was a living example of female church leadership. In 1921, she filed to divorce her second husband, Harold McPherson, claiming cruelty and desertion. Then, in 1926, she disappeared for months, later claiming she had been kidnapped and taken to Mexico. The crime story may well have been a ruse to meet up with a lover. ${ }^{67}$ Finally, in 1936, McPherson clarified her stance on gender roles in the church, calling for 
an end to discrimination against women and stating that "sex has nothing to do with the pulpit and pants don't make preachers." 68

In other ways, however, she fit well into the fundamentalist fold. McPherson never dropped her militant opposition to evolution, she welcomed William Jennings Bryan into the pulpit at Angelus, and she shared his sense that Darwinism had borne evil social fruits. As the New Yorker described her views in 1927, evolution is "poisoning the minds of the children of the nation. It is responsible for jazz, bootleg booze, the crime wave, student suicides, Loeb and Leopold, and the peculiar behavior of the younger generation." ${ }^{69}$ While McPherson made efforts to attract a multiracial congregation at Angelus, she was friendly with the California $\mathrm{Ku}$ Klux Klan, which helped pay for the construction of the gleaming edifice. And in 1938, shortly after Gerald Winrod ran in the Kansas Republican primaries for US Senate-being denounced as the "Jayhawk Nazi" by his political opponents-McPherson invited him to Los Angeles for a series of sermons. They had evangelized together, and Defender articles routinely appeared in Foursquare publications. While she bent to the outcry his first few appearances caused, and canceled the rest, his views by 1938 were well known. McPherson was ambivalent about the place of Jews in American political and spiritual life. She had given voice to common racist stereotypes of Jews as subversive and money hungry, even if at other times she warned against their persecution. ${ }^{70}$

The key to her willingness to invite Winrod, however, was most likely their shared antievolutionism and anticommunism. In early 1934, once again flouting the gender stereotype, Sister Aimee staged a traveling debate with Charles Lee Smith, the notorious atheist who had funded Ivanov's ape-human breeding research. With a variety of props, including a large cardboard cutout of a gorilla, McPherson attacked the weak points of evolutionary science and contended that Darwinistic ideas encouraged immoral behavior. ${ }^{71}$ That this behavior could lead in communistic directions was evident in a cartoon on the front page of the Foursquare Crusader. In "Communism in Operation," a giant octopus stretched out on a map of Europe, with a stereotypically bearded and hatted Russian Communist head perched awkwardly on the center of its body. Its three main tentacles, each of which grasps a lighted torch, are labeled "Atheism," "Evolution," and "Red Propaganda," the latter stretching across the Atlantic Ocean and slithering its way through the national capitol building, 


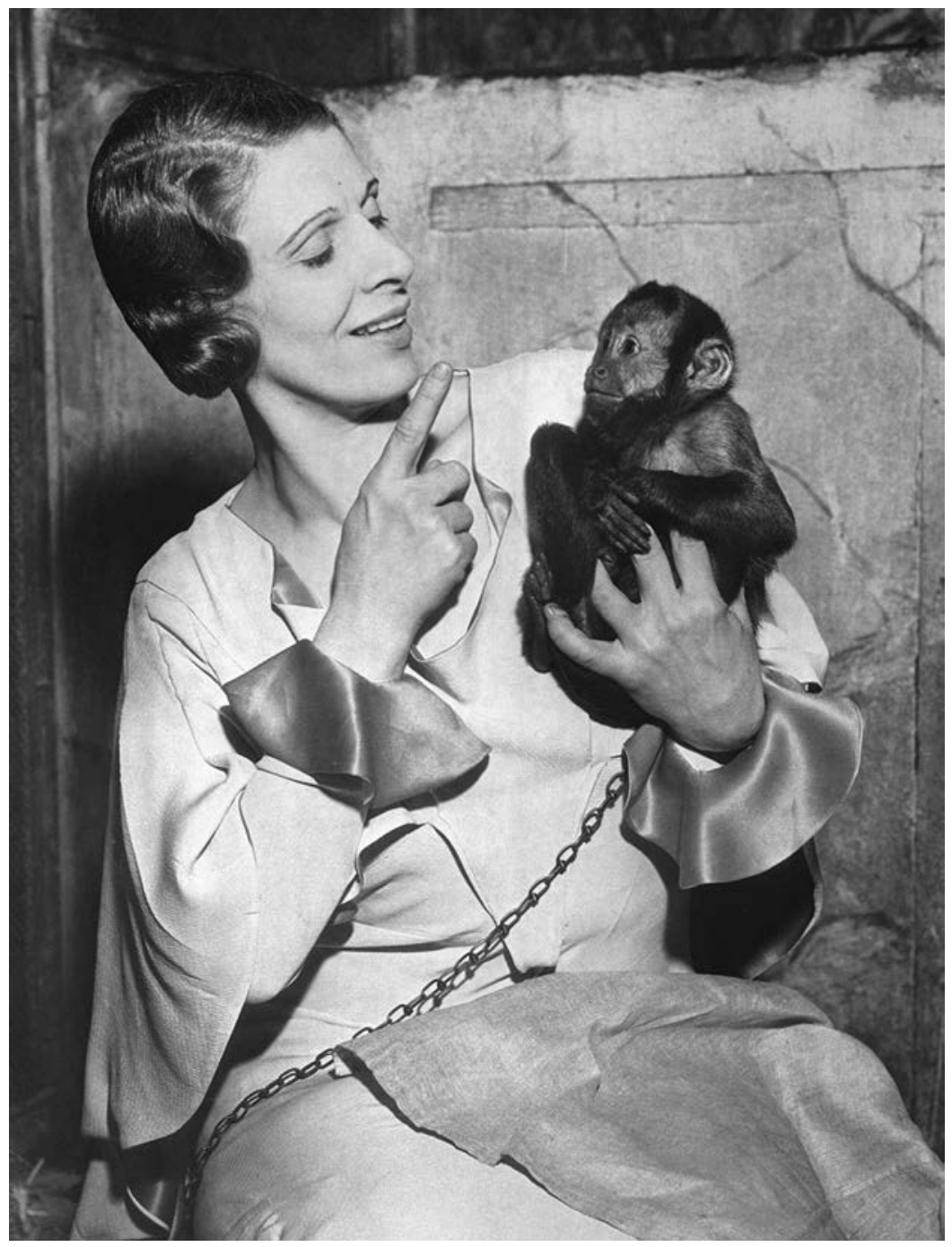

Figure 9. Aimee Semple McPherson, 1934. In a contrast to her gorilla-fighting image onstage, Sister Aimee strikes a more traditionally feminine motherly pose with a baby monkey at the Seattle, Washington, zoo, before holding a debate on evolution with atheist activist Charles Smith as part of a nationwide tour, January 1, 1934. Courtesy of Getty Images / Bettmann. 
a schoolhouse, a home, and a church. "Nothing is sacred to this devouring monster," proclaims the caption. "Communism aims at the destruction of our entire Christian civilization." 72

McPherson's message was familiar to legions of Christians as a result of the national tour that she had conducted in 1934, featuring her "illustrated sermon" titled "America, Awake!"73 The tour culminated in Los Angeles with a rousing election-eve rally to mobilize California voters against the gubernatorial candidacy of socialist Upton Sinclair, whose End Poverty in California campaign had gained him the Democratic nomination. ${ }^{74}$ Her address began with a providential vision of American history in which our God-inspired forebears, from the Puritans to the Founding Fathers to Abraham Lincoln, built the nation on the rock of religion. This foundation, however, was now threatened by atheistic communists, whom McPherson described as "subtle, powerful, relentless, [and] diabolic." Evoking the language of official Soviet atheism by labeling her enemies the "militantly Godless," she pinned responsibility for the spread of atheism among America's youth, as did Dan Gilbert, on the schools. Young people had been seduced into joining unbelieving groups such as "The Circle of the Godless" at the University of North Dakota and "The Legion of the Damned" at the University of Wisconsin.

Although she said little about evolution, she did make it clear that animalistic behavior followed logically from the erosion of religious faith. Take it away, she told her audiences, "and man becomes a beast!" Destroy the "moral code," the family and church, and young people become animals. "Denizens of the forest will soon be greeting new playmates!" she cried in alarm, though not without a sense of humor. No wonder that the rate of "juvenile delinquencies" was on the rise. "Darwin's theorizing on evolution," along with the writings of Thomas Paine, Voltaire, and American freethinker Robert G. Ingersoll, "have usurped the place of the Bible on the intellectual throne."

Then came the climax, in which the villains appeared onstage, while an unsuspecting Columbia sleeps on the US Capitol steps. "I see Satan, entering from the right, smirking and gloating over the recumbent form," declared McPherson. Satan then removed the cornerstone of those steps labeled "Faith." Next came a "grinning Bolshevik stealthily approaching, with his cap pulled low over his eyes," she announced. He removed the other cornerstone, labeled "home." In place of it, the Bolshevik replaced 
the "bomb of atheism." Red dynamite, indeed! After lighting the "fuse of subversion" and replacing the American flag with the red flag of revolution, the Bolshevik proclaims, "We are against God, we are against Capital, we are for a Socialist revolution.” But then Miss Columbia awakens. She "turns into a veritable fury," writes McPherson. In the stage version, Sister Aimee herself walked onto the stage at that critical moment, removed the red flag, and replaced it with Old Glory. The audience erupted with applause. The republic was restored. ${ }^{75}$

Given McPherson's near-celebrity status, her ecumenical spirit, and the drama of her illustrated sermons, she may have reached more Americans, in a face-to-face setting, with the message that evolution and communism were allied evils than did Riley, Norris, or Winrod. Unlike Elizabeth Knauss, Sister Aimee did not pen long, detailed analyses of events in China or the Soviet Union. She took a more simple, direct, and popular approach that resonated with the large audiences she attracted around the country. Precisely because she was less conservative in certain respects than were her prominent fundamentalist counterparts, she may have reached a wider swath of the American public with her Red Dynamite message.

Just as McPherson was making her name out West, Texas-based J. Frank Norris was expanding his fundamentalist base northward. In 1934, having pastored Fort Worth First Baptist for twenty-five years, Norris made a bid for national fundamentalist leadership by moving to Detroit to take over leadership of Temple Baptist Church. Located in a working-class area of the city inhabited by thousands of workers at the city's giant automobile plants, Temple Baptist had a relatively small congregation of 800 when Norris arrived. By 1939, over 6,000 Detroiters had joined the church. By the mid-1940s, Norris's combined congregation numbered some 25,000. ${ }^{76}$ Some 35,700 subscribed to his Fundamentalist, the successor to the Searchlight. ${ }^{77}$ All in all, Norris was one of the most powerful ministers in America.

He also would become one of the most effective popularizers of anticommunism during the 1930s and '40s. In late May 1936, a letter arrived in Norris's office from a young woman living in Philadelphia, Mississippi. Ila Fleming, whose father subscribed to Norris's Fundamentalist, was heading off to boarding school and wanted her own weekly copy of the paper. Not only did Fleming enclose payment for a six-month 
subscription, but she took advantage of a free book offer and asked Norris to send her Sovietizing America through Churches, College, and Consumer Co-operatives. Other books offered for sale on the form she returned included The Gospel of Dynamite (1935), which contained twelve sermons. One of these was "World-Wide Sweep of Russian Bolshevism, and Its Relation to the Second Coming of Christ." 78

Just as T.T. Shields had spoken of the need to blow up certain individuals and institutions with spiritual "dynamite," so did Norris employ this widely used metaphor. As if to justify its use in a religious context, Norris offered a quotation from the book of Romans on the book's title page, suggesting that the word itself appeared in the Bible: "The Gospelis the Power (Dynamite) of God. (Rom. 1:16)." While "dynamite" does

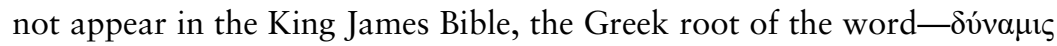
(dunamis) - is the basis for a variety of terms that do, ranging from "power" to "mighty works" to "wonderful works" to "miracles." 79 Given the explosive growth in attendance at both his churches, members of his congregations evidently responded to the "dynamite" of his style and the sense that he was filled, and filling them, with the power of God.

Not only did Norris continue preaching in the style he had perfected in Fort Worth, but he also continued to tie together the threats of communism, evolutionism, and racial integration, a theme to which he gave increasing prominence. In "The World-Wide Sweep," delivered in 1931, Norris drew upon chapter 5 of the Epistle of James, in which James warns the rich exploiters of their laborers of the coming return and judgment of Jesus. Reviewing recent world events, Norris interpreted them in light of prophecy. Revolutions; lack of faith (what he called "the black night of atheism"); conflict between the rich and the poor ("a fight to the finish"); and the rise of an "iron dictator"-all of these were predicted by the Bible. Citing Gog and Magog from the book of Revelation, Norris told his congregation that these predictions were coming true in Russia, where a "casteless society" was developing. Soviet leaders were campaigning under the red flag of communism and the black flag of atheism. They were "sweeping" through Asia, where China was the most "fruitful field." Given the extremes of wealth and poverty, it was the most likely place where Sovietism could enable the "bottom rail" to replace the top, an analogy that Norris identified with his Texas roots. Not only were the Russians out to level the social classes, but they aimed to erase "all national 
lines, all racial lines, that there is to be no color lines, the negro has equality with the whites." As if this were not evil enough, the Bolsheviks were also spreading atheism, and one of the "points of attack" was America, as evidenced by the spread of the "philosophy of evolution." "There is no such thing as Theistic Evolution," he stated. ${ }^{80}$ In a sense, Norris agreed with his communist opponents that there was no dilly-dallying middle ground-one must take sides. If they chose God, Norris assured his flock, then they would be ready for Christ's return.

Since Norris was telling his followers that their duty was to accept Christ as the only way to save themselves from the mess that humanity had made of the world, one might imagine that he chose to abstain from taking sides in the labor battles raging among working-class Americans. But Norris stood at the center of the war for the hearts and minds of Detroit autoworkers in the 1930s. And he was hardly the first nationally known cleric to do so. In the 1920s, a young Reinhold Niebuhr, fresh out of seminary, denounced Henry Ford's treatment of workers and publicly supported their right to organize unions. ${ }^{81}$ During the Depression decade, the famous and infamous "radio priest" Father Charles Coughlin gained a wide following among those who toiled in the auto plants. ${ }^{82}$ Like Coughlin, Norris claimed that he was interested in the spiritual and physical welfare of working people. He supported their right to engage in collective bargaining but nevertheless urged them to reject the Congress of Industrial Organizations (CIO) and its most prominent leader, John L. Lewis, as their mortal enemy. Norris not only preached this message at Temple Baptist, but he also delivered revival-style sermons at the Baptist Tabernacle, on downtown Detroit's Woodward Avenue. Each week, those sermons were then rebroadcast on radio station WJR, and then reprinted in the pages of the Fundamentalist.

Not for nothing did Zygmund Dobrzynski, the national director of organizing at Ford for the CIO-affiliated United Auto Workers (UAW), devote an entire article in the UAW newspaper to Norris, whom he accused of betraying the cause of the labor unionism in the guise of friendship for workers. Using a New Testament analogy, Dobrzynski likened Norris to Judas who "sold out the ONE who had led the oppressed peoples of those days in protest against human bondage." Contrary to his claims in favor of democracy, Norris was a "raving minister" using the "pulpit as a mask to promote dictatorship." 83 
In his sermons delivered in Detroit, Norris did not directly address the connection between evolution, communism, and the CIO. He did, however, direct his fire at modernist clergy, whom he identified in one sermon as the "hidden hand" behind the landmark Flint sit-down strike of 1937 that succeeded in unionizing General Motors. The guilty parties included Rev. Harry F. Ward, who had been identified back in 1925 by Chattanooga's T. W. Callaway as a player in the communist context of the Scopes trial. According to Norris, Ward had sent one of his representatives to Detroit to aid John L. Lewis and the CIO. Norris identified Ward as "chairman and prominent ruling spirit of the ultra-radical, revolutionary, and I.W.W.-defending American Civil Liberties Union.” He joined Callaway in describing the ACLU as a "supporter of all subversive movements." 84

If Norris did not connect the dots between evolution, communism, and industrial unionism, Dan Gilbert was pleased to do so. In "The Rise of Beastism," published in 1938 in Moody Monthly, the young evangelist redeployed his argument about Marxist "beast" doctrine and applied it to the burgeoning movement for industrial unionism. In Gilbert's eyes, Darwin's ideas boiled down to the proposition that progress is achieved by the strong crushing the weak. Gilbert then argued that communist rule meant the "reign of brute force." As for the conduct of the labor movement, Gilbert claimed that until recently, working "men" had rejected this communist idea and relied instead on the tactic of peaceful picketing, aiming to win over public opinion. This was "the American way, the Christian way." But in the past year, the "amazing vogue" of the European-based sit-down strike heralded a rise in "beastism." Instead of appealing to public opinion, workers, led by "radicals and communists," were seizing private property and relying on "organized lawlessness and terrorism." 85 Not only was the sit-down strike a product of communist evolutionism, but it was a fulfillment of prophecy. The rise of beastism as reflected in the CIO was "a sign that the spirit of Antichrist is abroad in our land." The prophets had foretold that the Antichrist would rule by "brute force" and that his dictatorship would be based on terrorism and lawlessness. In the face of this "swelling tide of beastism," it was the duty of Christians to "exercise every effort" to resist that demonic force.

Dan Gilbert's application of the concept of "beastism" to the phenomenon of the sit-down strike was a remarkable expression of creationist 
politics. Gilbert managed to explicitly connect Darwinian evolution, Marxist communism, labor movement politics, and biblical prophecy. A seasoned journalist writing in one of the most popular evangelical publications in America with forty thousand subscribers, Gilbert knew how to communicate with the masses. ${ }^{86}$ Though J. Frank Norris and Gilbert's close associate William Bell Riley were not collaborating closely at this point, Gilbert's piece complemented the fire-and-brimstone preaching that Norris did in Detroit to combat the CIO. If any of Norris's listeners read Gilbert's piece in Moody's, one imagines that they would be nodding their heads in easy agreement.

From the onset of the Great Depression to the end World War II, conservative-minded Americans had numerous opportunities to learn about the intertwined evils of communism and evolution. Depending on who taught this lesson, those "evils" might or might not have been further interwoven with the world Jewish conspiracy, the CIO, sit-down strikes, sex education, dancing and drinking college students, Freud, or the Chinese revolution. Remaining consistent was the idea that what George McCready Price labeled "Red Dynamite" posed a mortal threat to American and world civilization. Over the next two decades, as the Cold War profoundly shaped culture and politics, and as evolutionary biologists consolidated the "modern synthesis" of Darwinism and population genetics, that threat would be reinterpreted by a new generation in distinctive ways. 